\title{
Introduction to Pasture Ecology
}

\author{
Ed Rayburn \\ West Virginia University Extension Service, Morgantown, WV \\ ed.rayburn@mail.wvu.edu
}

Pasture-based livestock production is an integrated process. Plants intercept solar energy, take up soil water and minerals, making carbohydrates and proteins to feed themselves. Animals graze the pasture. Microbes in the animal's rumen digest the forage and are then digested by the animal to provide energy, protein, and minerals for animal maintenance, growth, and milk production. Dead plant tops and roots along with manure and urine provide energy and protein to soil organisms. The soil organisms maintain soil pore space and structure, provide water infiltration and soil water holding capacity, and cycle nutrients into forms that can be taken up by plants. The majority of minerals are cycled back to the soil in dead plant material and manure and urine from the animals. These nutrients are then used to grow another flush of pasture.

The interplay of sunlight, plants, soil, and animals are parts of pasture ecology. Livestock producers who understand pasture ecology are prepared to be better managers since they understand how the system works and how to adapt to change and apply research and experience from other farms to their farm. This introduction to pasture ecology will discuss components of the pasture ecosystem: plants, animals, soil, and climate from an energy flow and nutrient cycling perspective.

\section{Optimal environment vs. limiting factors}

Solar energy flows through the food chain or web (tropic levels) while nutrients cycle. Plants (producers) intercept and fix solar energy through photosynthesis. Some plants (legumes) fix nitrogen, which is needed to make proteins, from the air. Grazing animals (primary consumers) eat plants to get solar energy, protein, and minerals. Higher level consumers are predators, omnivores, parasites, and detritus feeders or decomposers. The goal of pasture-based livestock production is to capture sunlight and convert it to cash through a livestock enterprise.

Each plant, animal, bacteria, protozoa, and fungus has its niche or place in the ecosystem. All organisms do best when they live in an environment that provides all their resource needs (temperature, nutrients, protection from predators and pest, ability to reproduce). If any one of the needed resources is below a lower threshold or above an upper threshold that resource becomes the limiting factor to the health and productivity of the organism. If a second organisms is better adapted to this level of available resource it will be more healthy and productive and will out compete the first for space and use of other resources. When managing pasture plants or animals we need to know the optimal resource 
conditions needed by the plants and animals and provide them when possible. When not possible we should look to alternative plants and animals that do well within these limiting resource constraints.

Plant species differ in preferred thermal and radiant environment, growth habit, life history, nutritional quality, and anti-quality components. There are basic principles that apply to all plants. Some plants like it hot, some like it cool. Some need full sun, others tolerate shade. Some need long days to reproduce, others need short days. Some plants grow upright, some along the surface of the soil. Plants differ in their cell wall thickness and cell contents due to species, growth age, and time of year. Some plants have toxins, others provide antitoxins to toxins. There are grasses, legumes, forbs, shrubs, trees; tall plants, short plants, plants that have rhizomes and stolons and those that grow as a bunch of tillers. Some plants have roots that are fibrous, some have taproots. Some plants reproduce vegetatively, some sexually every year, others their first year then die, some live for two years then produce seed and die. Knowing the characteristics of the plants in the pasture helps us understand how to manage the plants and the pasture.

\section{Pasture height impact on plants and animals}

Canopy height is a pasture characteristic that determines plant light interception and impacts growth (Fig. 1 A). As canopy height increases light interception increases, forage mass increases, and light transmission decreases. Young leaves increase in photosynthesis as light interception increases. At full light interception older leaves begin to die and growth plateaus, new leaf growth being offset by leaf death. High light interception allows for high forage production but at the expense of tiller density. Light transmission into the lower canopy stimulates increased tiller density. Canopy height should be managed to meet the desired management outcomes.

Pasture height also impacts animal forage dry matter intake (Fig $1 \mathrm{~B}$ ). High forage mass allows for high relative dry matter intake. When animals first enter a pasture, their grazing can be highly selective. Selective grazing is the ability of animals to select and eat forage of a higher or lower quality than the average forage in the pasture. As animals consume forage selective grazing diminishes. Below a 4-inch canopy height livestock forage intake decreases due to lack of availability. As forage grows and ages its nutritional quality decreases.

\section{Carbohydrate reserves power early plant growth}

When a plant is defoliated it uses photosynthesis from remaining leaves and reserve carbohydrates (sugar and starch) to power new growth (Fig. 2). As this happens carbohydrate reserves decrease. As new leaves grow and intercept light these young leaves are efficient in photosynthesis, powering growth, and when carbohydrate production is adequate rebuild carbohydrate reserves. Plants differ in where they store reserves (Fig. 3). Orchardgrass stores carbohydrates in the tiller bases below the leaves. Tall fescue stores carbohydrates in tiller bases and in rhizomes which are underground and protected from over grazing. White clover 
stores carbohydrates in its stolon and tap roots. Red clover stores carbohydrate reserves in it tap root. Providing adequate rest intervals between defoliation events is essential for restoring carbohydrates reserves for future forage growth.

Cool season grasses do not store carbohydrate reserves in their root. When defoliated some roots die, then roots regrow as plant energy balance allows. Grass root health is a function of severity of defoliation and rest interval between defoliations (Fig. 4). When rest interval is adequate sever defoliation does little damage to the root system. Severe defoliation over extended periods of time is detrimental to root health.

Livestock also store energy reserves. The main energy reserve is fat seen in body condition score (Fig. 5). Beef cattle have the highest conception rate after calving when they have a body condition score of 6 at calving. When wintered outside in cold environments fat insulates the body and also provides energy reserves when food intake is limited making it easier for fat animals to tolerate cold weather.

\section{Pasture defoliation management}

The main tools used to manage pasture ecosystems are stock density and occupation period. Stock density is the number of animal units (AU, $1000 \mathrm{lb}$ animal live weight) per acre for a short period of time. Stocking rate is the number of $A U$ per acre for the year, grazing season, or other long time periods.

A 30-cow herd on 30-acres of continuously grazed pasture has a stocking rate of one cow per acre and an occupation period of the grazing season. If put under rotational grazing using six, five-acre paddocks the stock density becomes six cows/acre (30 cows $/ 5$ acre paddock $=6$ ). When the occupation period is 7-days the rest interval is 35-days before animals go back into a previously grazed paddock. On-farm experience found that increasing paddock numbers (increasing stock density) resulted in more days of grazing (Fig.6 A) compared to previously reported days of grazing under continuous grazing.

Stocking rate and pasture growth rate determine the balance between forage demand and forage supply over the year. As stocking rate increases available forage is shared between more animals. At low stocking rates individual animal performance is high but due to low animal numbers production per acre is low. As stocking rate increases gain per head decreases but gain per acre increases since more animals are present. At some point gain per head is so low that adding another animal reduces gain per acre (Fig 6 B). Maximum animal production per acre is achieved at one stocking rate but the maximum net income is achieved at a lower stocking rate depending on the marginal costs per animal.

\section{Competition between plants}

Plants compete with each other for sunlight, water, and nutrients. When allowed, tall growing plants overtop short plants allowing them access to more sunlight. Deep rooting plants 
will be more competitive for water than shallow rooted plants. However, in a dry year with light showers that only wet the upper soil plants with dense fibrous shallow roots will capture the water before it penetrates deep enough for the deep-rooted plants.

Grasses are more competitive than legumes when nitrogen is available and when potassium is low. When legumes fix nitrogen for a few years, the nitrogen status of the soil increases and stimulates grass growth. Vigorous grass growth can crowd out the legumes for a while until the excess nitrogen is used up allowing the legumes to come back into the stand. Due to the nature of their roots, grasses take up potassium more readily than legumes. When managing legumes to provide pastures nitrogen, maintaining soil test potassium in the optimum range keeps potassium from limiting legume health and vigor.

\section{Climate and weather}

Climate and weather determine plant growth. Plant growth is powered by sunlight as impacted by air temperature and soil moisture. Climate is the average air temperature and rainfall over the growing season and describes the average pasture growth curve. Weather varies from year to year with a given years pasture growth being a function of that year's weather (Figure 7). Yield of cool season forages in WV, VA, OH, PA and KY vary 25- to 30percent about the average 66-percent of the time. Reducing the stocking rate on a farm by $15-$ percent provides risk management against drought 85-percent of the time.

\section{Nutrient cycling}

Grazing management is the least cost means of harvesting forage. Animals do the harvesting and manure spreading at the same time without the need for machinery, fuel, or significant human labor. The value of nutrients cycled is very high. The fertilizer value in a ton of dry forage is directly related to the forage nutritional quality, here defined as crude protein (Table 1). As forage quality increases fertilizer nutrient content increases. Using the 2021 price of fertilizers in WV, the fertilizer value of forage feed to cattle ranges from $\$ 40$ to $\$ 70 /$ ton dry matter.

Most of the nutrients consumed by livestock are excreted back out. Energy is the main feed component used for maintenance, activity, growth, and milk production. Some of the protein and minerals are used in growth and milk production. Most of them are returned to the pasture in the manure and urine. An extreme example is a dry, mature cow in the second trimester of pregnancy (prior to growth of the fetus) that is not gaining or losing weight. This animal returns about $100 \%$ of the consumed protein and minerals back to the pasture. More nutrients are cycled in pastures then in hay feeding since pasture quality tends to exceed hay quality (Table 2). Nutrients cycled over the year when feeding a $1250 \mathrm{lb}$ cow weaning a $500 \mathrm{lb}$ calf exceed the nutrients removed in the calf by a factor of three. The value of fertilizer nutrients cycled over the year are about 50 to 60-percent of the value of a calf or cull cow sold in the fall. 


\section{Soil and soil life}

Soil is made from rocks by sunlight, weather, plants, and animals. Plant root and leaf death and animal manure and urine feed and stimulate soil life. Soils hold nutrients for plants, capturing water on rainy days, and holding water for plants between rainy days. Soil life cycle and hold nutrients from plants and animals for plant growth. Soil life opens pore space to let rainwater infiltrate into the soil. Soil organic matter helps hold more plant available water between rains and stabilized soil structure. Soil life greatly exceeds plants and grazing animal life on top of the soil (Table 3). An acre of pasture soil under rotational grazing will have more biomass of earthworms than of livestock. A good pasture under rotational grazing will have 70,000 to 100,000 nightcrawler earthworms per acre plus other types of earthworms. The nightcrawler burrows are major conduits for rainwater entering the soil. Other soil organisms provide different ecological services.

\section{Summary}

Pasture management impacts the plant community, animals, and soil health.

- Plant Community

- Rest interval between defoliations (impacts initial forage mass, carbohydrate reserves, root health)

- Light interception \& transmission at harvest (impacts yield, tiller density)

- Degree of defoliation (impacts plant growth, plant competition)

- Forage quality (impacted by legumes, forbs, age of forage, season)

- Duration of grazing period (impacts animals grazing regrowth)

- Animal

- Forage mass (impacts forage quality, animal forage intake, performance)

- Forage quality (impacts animal performance)

- Degree of defoliation (impacts selective grazing)

- Duration of grazing and stock density (impacts available forage)

- Soil

- Plant cover (impacts soil temperature, earthworm habitat, nutrient cycling)

- Soil health (impacts water infiltration, soil water holding capacity)

- Fertility (impacts species adapted to site, productivity of plants)

Pasture managers are ecosystem managers. Understanding the ecosystem help them be better managers. 


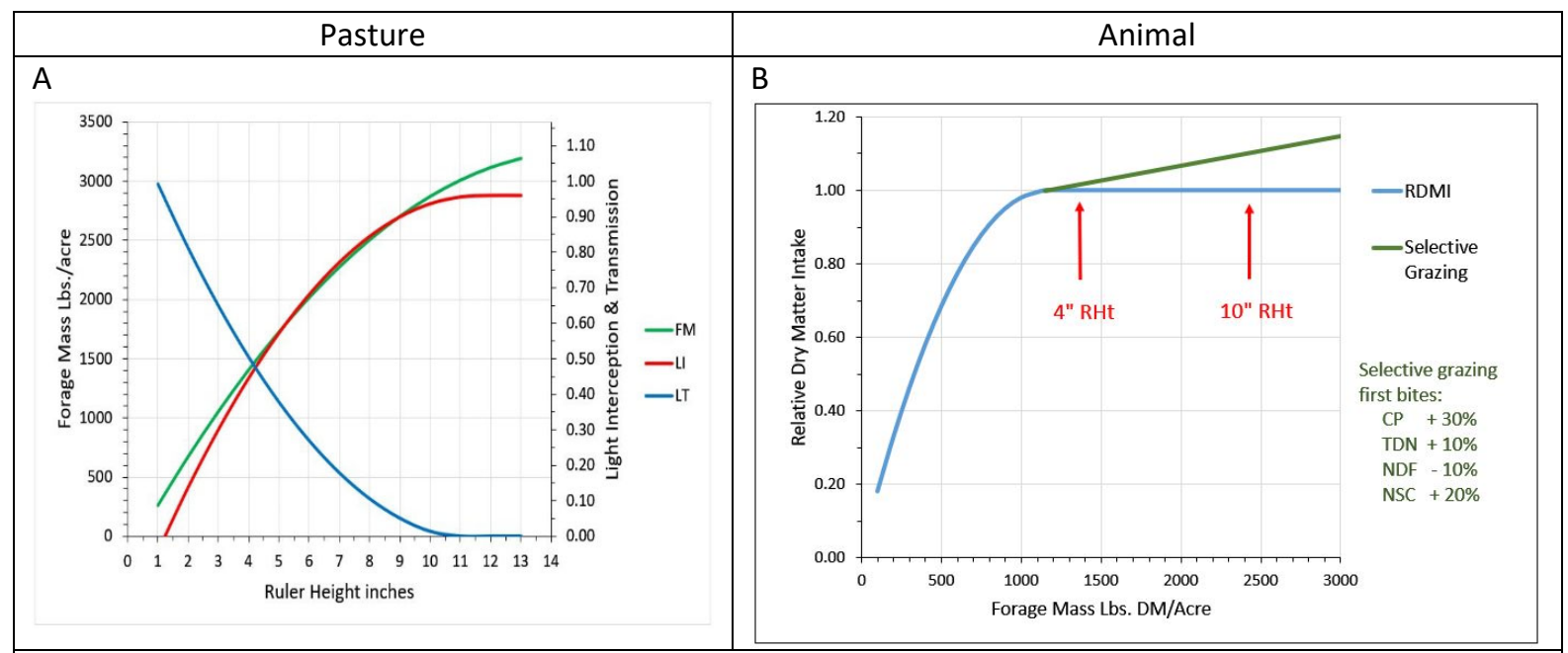

Figure 1. A. Ruler height determines pasture light interception (LI), light transmission (LT), and forage mass (FM). B. Pasture FM and use impact relative dry matter intake (RDMI) and selective grazing by livestock. Pasture FM below $1200 \mathrm{lb}$ dry matter/acre reduces RDMI due to lack of forage availability.

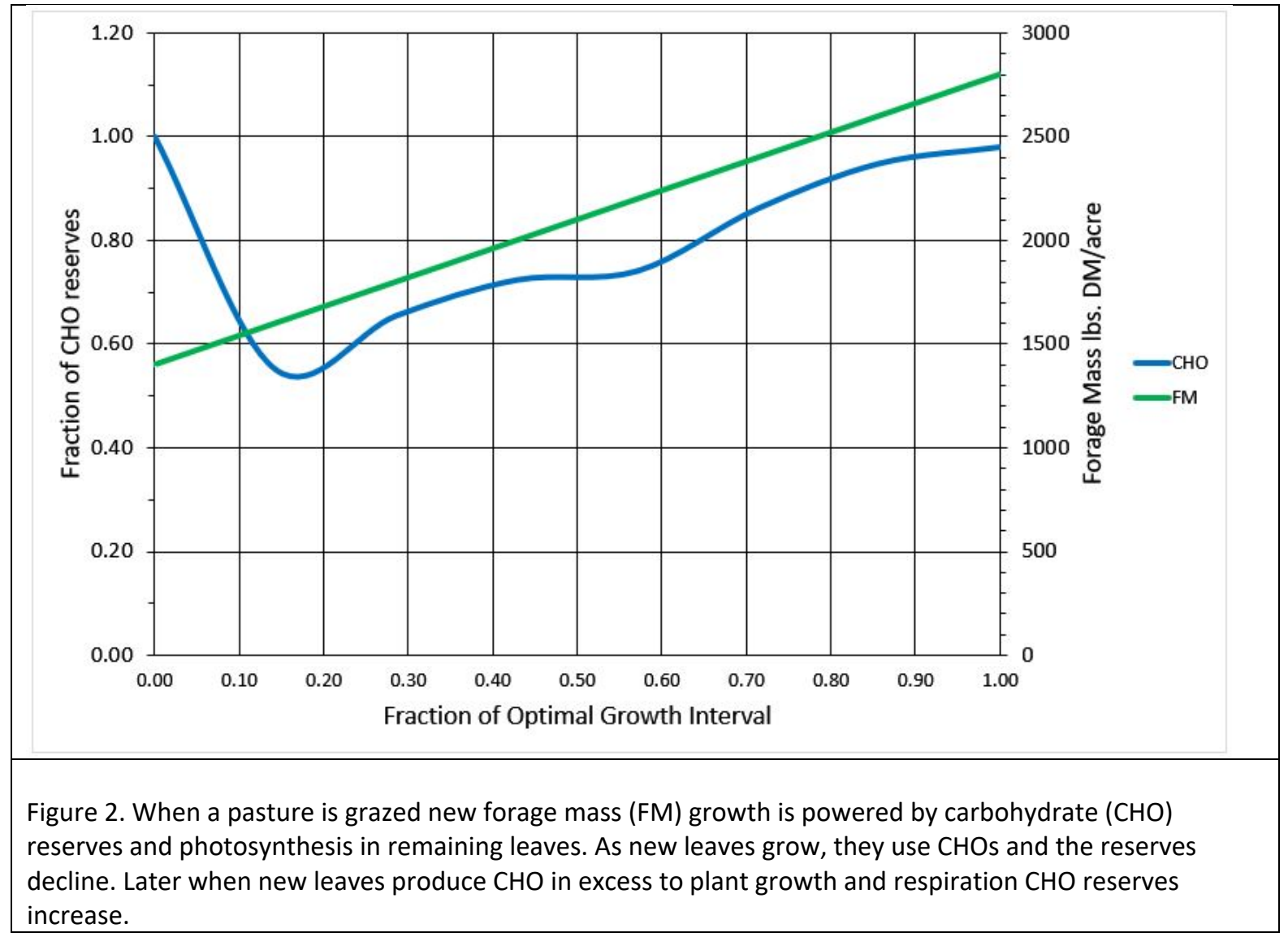




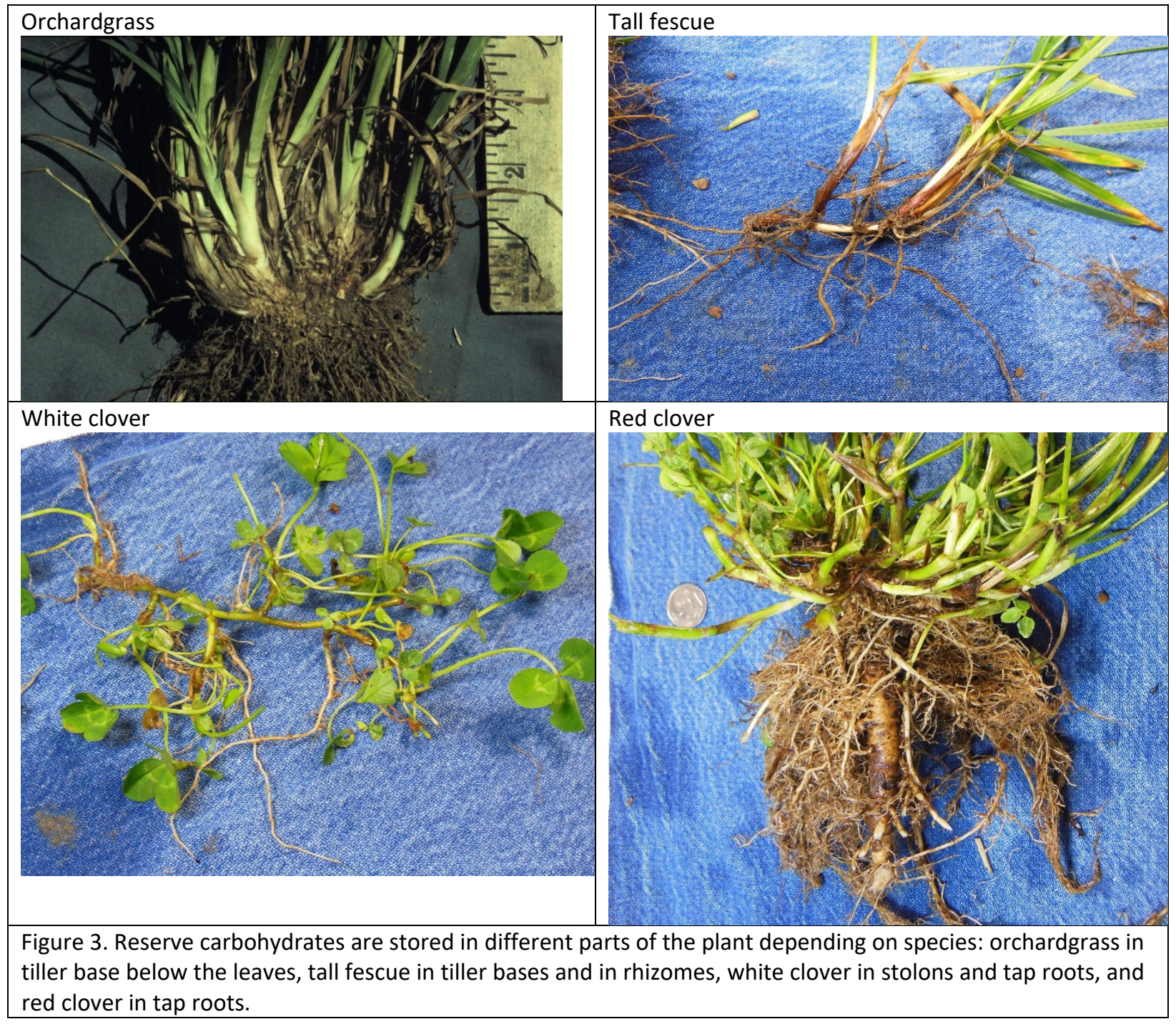



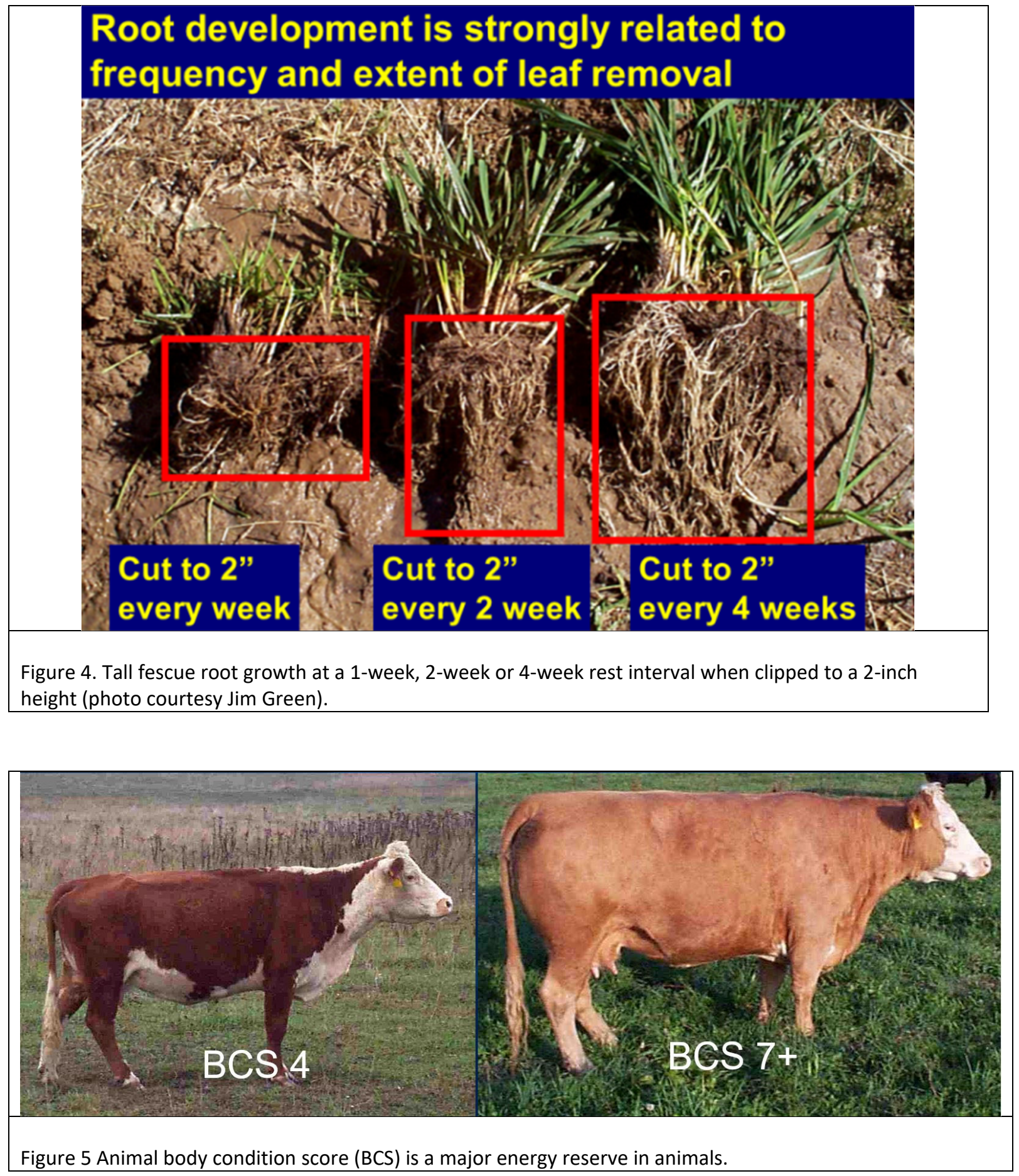


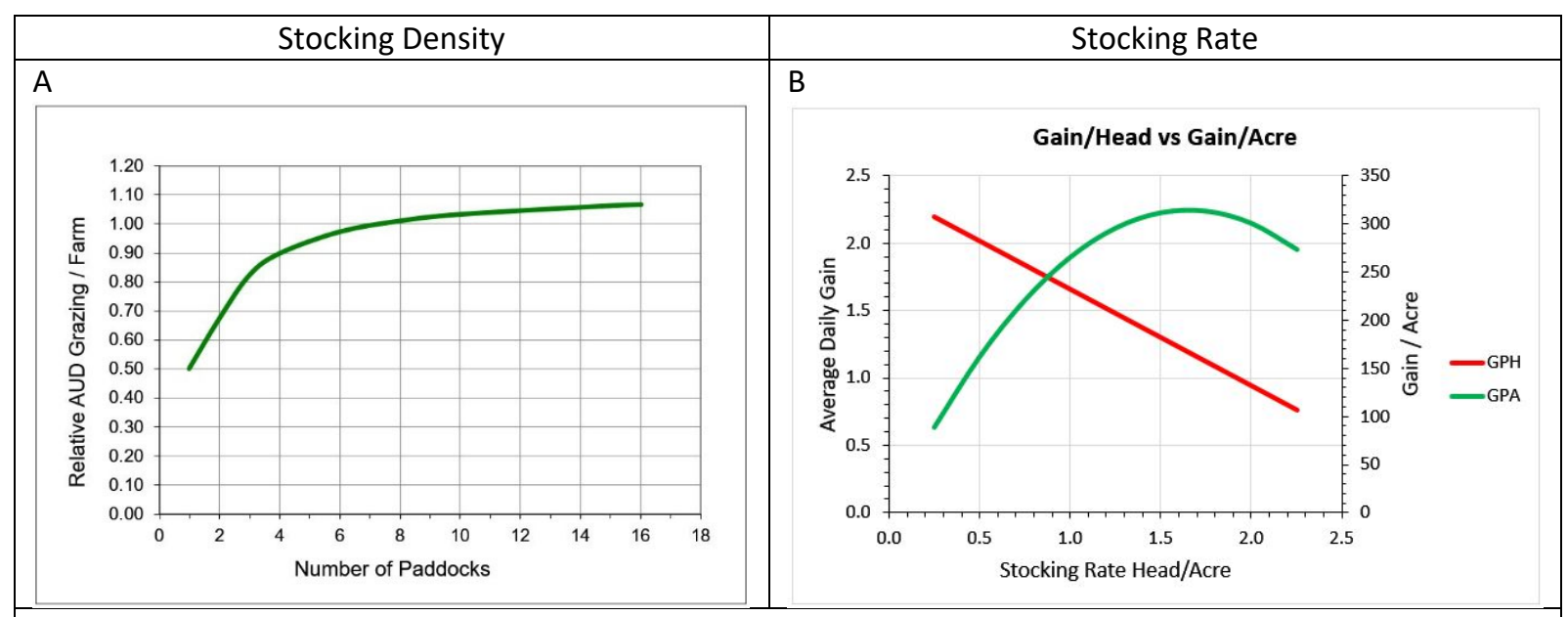

Figure 6. A. As number of paddocks increases stock density increases for a given rest interval. This increases grazing efficiency and pasture growth which provide more animal unit days (AUD) of grazing per farm per year. B. As stocking rate increases gain per head decreases but gain per acre initially increases, then plateaus, and then decreases. The economic optimal stocking rate is to the left hand side of maximum production per acre based on economics and risk aversion.
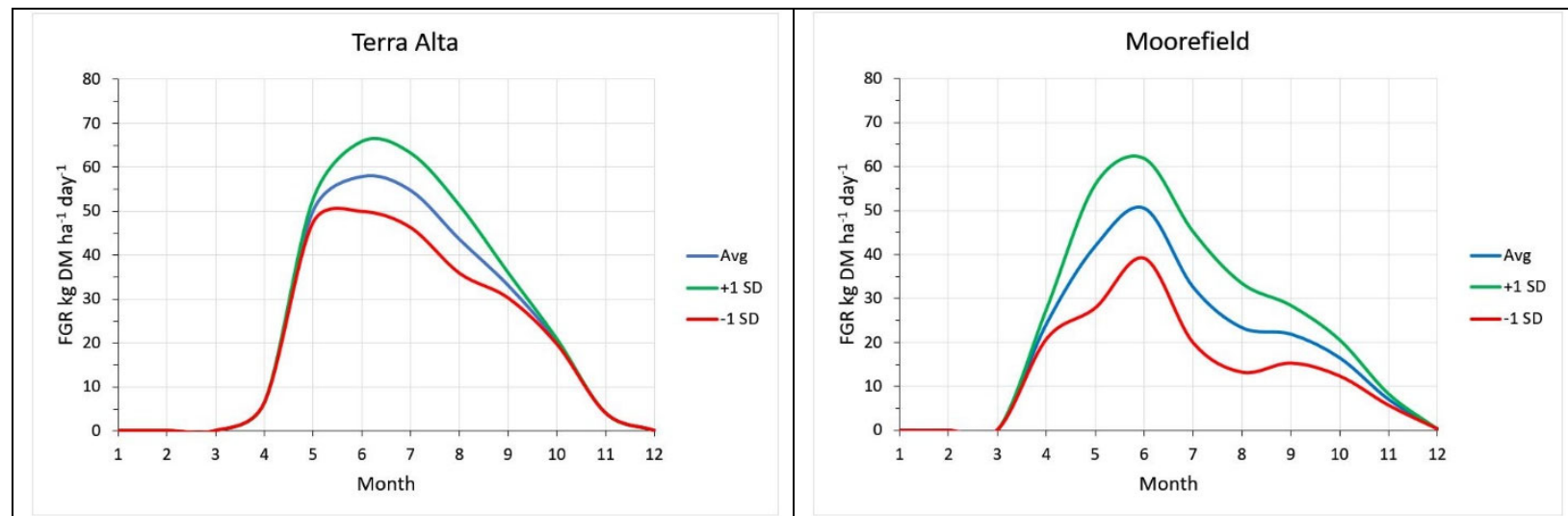

Figure 7. Climate determines the shape of the forage growth curve (Terra Alta, cool high rainfall climate, Moorefield, warm lower rainfall climate). Weather determines the variability about the average forage growth curve. The upper and lower lines show the one standard deviation (SD) range within which 66-percent of the years fall. 


\begin{tabular}{|c|c|c|c|c|c|c|c|}
\hline \multirow{3}{*}{$\begin{array}{l}\text { Forage } \\
\text { CP\% }\end{array}$} & \multicolumn{3}{|c|}{$\begin{array}{l}\text { Fertilizer Nutrient Content } \\
\text { Lb/ton DM }\end{array}$} & \multicolumn{3}{|c|}{ Fertilizer Nutrient Value $\$ / L b$} & \multirow{3}{*}{ Total value } \\
\hline & \multirow{2}{*}{$\mathrm{N}$} & \multirow{2}{*}{$\mathrm{P}_{2} \mathrm{O}_{5}$} & \multirow{2}{*}{$\mathrm{K}_{2} \mathrm{O}$} & $\mathrm{N}$ & $\mathrm{P}_{2} \mathrm{O}_{5}$ & $\mathrm{~K}_{2} \mathrm{O}$ & \\
\hline & & & & $\$ 0.58$ & $\$ 0.78$ & $\$ 0.41$ & \\
\hline & & & & \multicolumn{4}{|c|}{ Nutrient Values $\$ /$ ton DM } \\
\hline 6 & 19 & 10 & 33 & $\$ 11$ & $\$ 8$ & $\$ 14$ & $\$ 33$ \\
\hline 8 & 26 & 11 & 37 & $\$ 15$ & $\$ 9$ & $\$ 15$ & $\$ 39$ \\
\hline 10 & 32 & 12 & 41 & $\$ 19$ & $\$ 10$ & $\$ 17$ & $\$ 45$ \\
\hline 12 & 38 & 13 & 45 & $\$ 22$ & $\$ 10$ & $\$ 18$ & $\$ 51$ \\
\hline 14 & 45 & 14 & 49 & $\$ 26$ & $\$ 11$ & $\$ 20$ & $\$ 57$ \\
\hline 16 & 51 & 15 & 53 & $\$ 30$ & $\$ 12$ & $\$ 22$ & $\$ 63$ \\
\hline 18 & 58 & 16 & 57 & $\$ 33$ & $\$ 13$ & $\$ 23$ & $\$ 69$ \\
\hline 20 & 64 & 17 & 61 & $\$ 37$ & $\$ 13$ & $\$ 25$ & $\$ 75$ \\
\hline
\end{tabular}

\begin{tabular}{|c|c|c|c|c|c|}
\hline $\begin{array}{l}\text { Nutrients cycled or } \\
\text { removed }\end{array}$ & $\mathrm{N}$ & $\mathrm{P}_{2} \mathrm{O}_{5}$ & $\mathrm{~K}_{2} \mathrm{O}$ & Value of nutrients & Value of animal product \\
\hline \multirow[t]{2}{*}{ Value of nutrient $\$ / \mathrm{lb}$} & $\$ 0.58$ & $\$ 0.78$ & $\$ 0.41$ & & \\
\hline & \multicolumn{3}{|c|}{ Lb of nutrients } & & \\
\hline 6 AUM grazing & 147 & 39 & 140 & $\$ 173$ & \\
\hline 6 AUM hay feeding & 74 & 28 & 94 & $\$ 104$ & \\
\hline $500 \mathrm{lb}$ calf & 15 & 7 & 1 & $\$ 15$ & $\$ 650$ to $\$ 850$ \\
\hline $1250 \mathrm{lb}$ cull cow & 34 & 19 & 3 & $\$ 36$ & $\$ 800$ to $\$ 1000$ \\
\hline $100 \mathrm{cwt}$ milk & 56 & 21 & 18 & $\$ 56$ & $\$ 1600$ \\
\hline
\end{tabular}




\begin{tabular}{|c|c|}
\hline Organisms & Standing crop biomass lbs./acre \\
\hline \multicolumn{2}{|c|}{ Above ground } \\
\hline 1200 beef cow ${ }^{1}$ & 450 \\
\hline Pasture dry matter ${ }^{2}$ & 2500 \\
\hline \multicolumn{2}{|c|}{ Below ground } \\
\hline Pasture plant roots ${ }^{3}$ & 2500 \\
\hline Bacteria & 2052 \\
\hline Actinomycetes & 2052 \\
\hline Fungi & 6244 \\
\hline Algae & 219 \\
\hline Protozoa & 80 \\
\hline Nematodes & 62 \\
\hline Mites & 65 \\
\hline Collembola & 65 \\
\hline Earthworms & 624 \\
\hline Other fauna & 40 \\
\hline \multicolumn{2}{|c|}{ Adapted in part from Brady and Weil 2002} \\
\hline \multicolumn{2}{|c|}{ Cow weaning $600 \mathrm{lbs}$. calf needing 3 acres/year for pasture, hay and aftermath grazing } \\
\hline \multicolumn{2}{|c|}{ Cool-season grass-clover pasture, 10 inches tall at grazing. } \\
\hline \multicolumn{2}{|c|}{ Roots equal to top growth at grazing } \\
\hline
\end{tabular}

